Penggunaan Metode Inside Outside Circle untuk Meningkatkan Hasil Belajar IPS

\title{
Paradika Angganing
}

Universitas Veteran Bangun Nusantara Sukoharjo paradika_angga@yahoo.com

\section{Sejarah Artikel}

diterima 26/06/2019

\begin{abstract}
The research aims to improve learning outcomes of social science studies using inside outside circle method. It is classroom action research (CAR). The research subjects are 16 students. Data analysis techniques use comparative descriptive statistical analysis techniques. The data collection technique uses tests, observation and documentation, while the validation technique uses data triangulation techniques. The results show that the percentage of mastery learning increases each cycle. In the first cycle, the percentage of mastery learning reaches $75 \%$ or 12 students pass the mastery learning and $25 \%$ or 4 students fail the mastery learning. In the second cycle, the percentage of mastery learning increases to reach $87.50 \%$ or 14 students pass the mastery learning and $12.50 \%$ or 2 students fail the mastery learning. It concludes that inside outside circle method can solve the problems of social science in primary school.

Keywords: inside outside circle metods, mastery learning, social science studies
\end{abstract}

\begin{abstract}
Abstrak
Penelitian ini bertujuan untuk meningkatkan hasil belajar IPS menggunakan metode inside outside circle. Jenis penelitian adalah penelitian tindakan kelas (PTK) dengan jumlah subyek sebanyak 16 anak. Teknik analisis data menggunakan teknik analisis statistik deskiptif komparatif. Teknik pengumpulan data menggunakan tes, observasi dan dokumentasi, sedangkan teknik validasi menggunakan teknik trianggulasi data. Hasil penelitian menunjukkan persentase ketuntasan juga mengalami peningkatan tiap siklus. Persentase ketuntasan belajar siklus Imencapai $75 \%$ atau 12 siswa yang mendapat nilai tuntas dan $25 \%$ atau 4 siswa yang belum mendapat nilai tuntas. Pada siklus II persentaseketuntasan siswa meningkat hingga mencapai $87,50 \%$ atau 14 siswa yangmendapat nilai tuntas dan $12,50 \%$ atau 2 siswa yang belum mendapatnilai tuntas. Hasil penelitian ini menyatakan bahwa metode inside outside circle dapat digunakan untuk menyelesaikan permasalah dalam pembelajaran IPS di sekolah Dasar Kata kunci: metode outside inside circle, hasil belajar, IPS
\end{abstract}




\section{PENDAHULUAN}

\begin{tabular}{lr}
\multicolumn{1}{c}{ Pendidikan } & merupakan \\
suatuusaha sadar & dalam \\
mengembangkan kepribadian dan \\
kemampuan seseorang untuk belajar \\
didalam maupun diluar sekolah \\
danberlangsung seumur hidup.
\end{tabular}

Pendidikan yang berlangsung seumur hidup biasa dikenal dengan istilah pendidikan sepanjang hayat.

Seseorang dapat memilih berbagai jalur pendidikan yang sesuai dengan kebutuhanya.

Pendidikan bertujuan
menciptakan seseorang yang
berkualitas dan berkarakter sehingga memiliki pandangan yang luas kedepan untuk mencapai suatu citacita yang diharapkan. Pendidikan diharapkan mengajarkan seseorang untuk mampu beradaptasi secara cepat dan tepatdiberbagai lingkungan. Pendidikan memotivasi diri kita untuk lebih baik dalam segala aspek kehidupan, sesuai dengan UndangUndang sistem pendidikanNasional RI Nomer 20 Tahun 2003 pasal 3 menyatakan bahwa: Pendidikan Nasional berfungsi mengembangkan kemampuan dan membentuk watak serta peradaban bangsa yang bermartabat dalam rangka mencerdaskan bangsa bertujuan untuk mengembangkan potensi peserta didik agar menjadi manusia yang beriman dan bertaqwa kepada Tuhan Yang Maha Esa.

Pendidikan Nasional berfungsi mengembangkan kemampuan dan membentuk watak serta peradaban bangsa yang bermartabat dalam rangka untuk mencerdaskan bangsa yang bertujuan untuk mengembangkannya potensi peserta didik agar menjadi manusia yang beriman dan bertaqwa kepada Tuhan
Yang Maha Esa, berahklak mulia, sehat, berilmu, cakap, kreatif, mandiridan menjadi warga negara yang demokratis serta bertanggung jawab.

Melihat tujuan pendidikan nasional tersebut diharapkan kondisi pembelajaran di Indonesia menghasilkan siswa siswi yang berprestasi dan berkarakter. Kondisi pembelajaran di kelas sungguh memprihatinkan dikarenakan banyaknya siswa yang tidak memenuhi kriteria ketuntasan minimal (KKM) yang telah ditetapkan oleh masing-masing sekolah. Kondisi dimana siswa tidak bisa memenuhi KKM hampir terjadi di semua jenjang kelas dan semua mata pelajaran.

Menurut siswa mata pelajaran IPS adalah mata pelajaran yang membosankan dan kurang menarik. Kurangnya pengawasan dari guru terhadap kenyataan tersebut membuat siswa cenderung memiliki hasil belajar yang rendah terhadap suatu mata pelajaran, dan hal itu sangat berpengaruh terhadap prestasi yang diperoleh siswa. Dengan penelitian ini diharapkan dapat menumbuhkan dan mengembangkan minat siswa khususnya pada mata pelajaran IPS, sehingga siswa akan memperoleh prestasi yang baik dengan adanya minat belajar dari dalam diri siswa. Menumbuhkan minat belajar IPS salah satunya dengan menggunakan metode inside outside circle dimana metode ini mengajak siswa untuk saling bertukar informasi yang didapatnya dalam lingkaran baik lingkaran dalam maupun lingkaran luar (Azhary, 2013:67) 
Kompri

(2016:

218)

berpendapat bahwa belajar berarti usaha mengubah tingkah laku. Jadi belajar akan membawa suatu perubahan pada individu-individu yang melakukan kegiatan belajar. Perubahan tidak hanya berkaitan dengan penambahan ilmu pengetahuan tetapi juga dalam bentuk kecakapan, keterampilan, sikap, pengertian harga diri, minat, watak dan penyesuaian diri. Dengan demikian dapat dikatakan bahwa belajar itu sebagai rangkaian kegiatan jiwa raga, psiko-fisik untuk menuju kearah perkembangan pribadi manusia seutuhnya.

Helmawati

(2016:205)

menyatakan prestasi adalah hasil dari pembelajaran. Semua itu diperoleh dari evaluasi atau penilaian. Setiap orang akan memiliki hasil belajar atau prestasi yang berbeda antara satu dengan yang lain. Prestasi yang diperoleh dari hasil pembelajaran setelah dinilai dan dievaluasi dapat saja rendah, sedang, ataupun tinggi.

Kondisi serupa juga terjadi didalam pembelajaran IImu Pengetahuan Sosial (IPS) di kelas III SDN Wonokarto I Kecamatan Wonogiri, Kabupaten Wonogiri. Guru belum menggunakan metode pembelajaran yang menarik dan pembelajaran hanya mengarah pada penguasaan hafalan konsep dan teori saja. Pembelajaran yang menghafal konsep menjadikan siswa perhatiannya tidak maksimal pada saat guru menyampaikan materi. Dari 16 siswa, terdapat $7(43,75 \%)$ siswa yang tidak serius dalam mengikuti pembelajaran. 7 siswa tersebut terdiri dari; 1 siswa yang mengantuk, 2 siswa yang sibuk bercakap-cakap dengan teman, 2 siswa melamun, 1 siswa sibuk bermain dengan alat tulis yang dimilikinya, dan ada 1 siswa yang selalu tidak mau mengerjakan Pekerjaan Rumah (PR). Hasil pembelajaran pun juga masih jauh dari harapan, karena dari batas $\mathrm{KKM}=70$, terdapat $9(56,25 \%)$ siswa yang belum mencapainya. Hal itu berarti hampir 50\% siswa yang ada di kelas III SD Negeri Wonokarto I masih memiliki tingkat kejenuhan yang tinggi untuk mengikuti pembelajaran IPS, dan itu berdampak pada hasil belajar mereka karena lebih dari $50 \%$, atau tepatnya 9 siswa dengan presentase $56,25 \%$ mendapatkan nilai rata-rata yang tidak tuntas pada pembelajaran IPS.

Kegiatan inti pada proses pembelajaran yang diterapkan guru cenderung menggunakan metode ceramah, sehingga masih banyak siswa yang ramai sendirisaat diterangkan guru, antusias siswa dalam belajar IPS rendah,dan kurangnya media pembelajaran. Sapriya (2015:11) Pendidikan IPS adalah seleksi dari disiplin ilmu-ilmu sosial dan humaniora, serta kegiatan dasar manusia yang diorganisasikan dan disajikan secara ilmiah dan psikologis untuk tujuan pendidikan. Kegiatan akhir guru menyimpulkan pelajaran yang telah disampaikan dan memberikan soal latihan. Hal tersebut menyebabkan pembelajaran IPS berlangsung secara monutun atau kurang bervariasi.

Masalah masalah yang timbul dalam pembelajaran di atas merupakan suatu kendala yang menyebabkan hasil belajar IPS yang dicapai rendah atau masih dibawah KKM. Melihat hasil belajar tersebut maka akan ditawarkan metode inside outside circle untuk meningkatkan hasil belajar IPS. Lie (20014:65) menjelaskan, pembelajaran Inside- 
Outside Circle adalah metode pembelajaran yang dikembangkan oleh Spencer Kagan untuk memberikan kesempatan pada siswa agar saling berbagi informasi pada saat yang bersamaan. Pembelajaran dengan metode Inside-Outside Circle mengembangkan sebuah pembelajaran yang inovatif dan variatif. Dengan demikian apakah metode inside outside circle dapat meningkatkan hasil belajar siswa kelas III SD Negeri Wonokarto I Kecamatan Wonogiri Tahun Pelajaran 2015/2016?

\section{METODE}

Penelitian ini adalah penelitian tindakan kelas (PTK). Subyek penelitian adalah siswa kelas III SD Negeri Wonokarto I Kecamatan Wonogiri Kabupaten Wonogiri Tahun Ajaran 2015/2016 yang berjumlah 16 siswa, terdiri dari 9 siswa laki laki dan 7 siswa perempuan. Teknik penggumpulan data yang digunakan adalah tes, observasi, dokumentasi. Teknik validasai data menggunakan teknik Triangulasi. Teknik analisis yang digunakan dalam penelitian ini adalah dengan menggunakan analisis statistik deskriptif komparatif yaitu membandingkan nilai tes awal dan antar siklus maupun dengan indikatorkinerja. Dilanjutkan refleksi untuk mengkaji dan menilai hasil tindakan masing-masing siklus untuk dijadikan masukan terhadap pelaksanaan pembelajaran. Indikator kinerja setiap siklus adalah minimal 13 siswa mendapatkan nilai lebih dari 70 . Menghitung ketuntasan belajar klasikal dengan cara :

$$
\frac{\text { banyak siswa tuntas belajar }}{\text { banyaksiswa keselwrwhan }} \times 100 \%
$$

\section{PEMBAHASAN}

Kondisi awal pembelajaran IPS dikatakan tidak maksimal karena 6 siswa yang memenuhi nilai Kriteria Ketuntasan Minimal (KKM). Banyak siswa yang perhatiannya tidak maksimal saat pembelajaran berlangsung. Hal tersebut tampak dari 16 siswa Jumlah siswa yang belum mencapai KKM masih tinggi, yaitu $56,25 \%$ atau sebanyak 9 siswa dari jumlah 16 siswa kelas III. Guru masih sangat banyak mendominasi proses pembelajaran (Teacher Centered) dengan cara menghafal konsep dan teori.

Kegiatan pembelajaran siklus I dilaksanakan dengan metode inside outside circle, guru mengkondisikan siswa untuk membagi siswa di dalam kelas menjadi dua kelompok besar, satu kelompok terdiri dari 8 siswa. Data perbandingan nilai dari prasiklus dan siklus I adalah sebagai berikut:

Tabel 1. Persentase Perbandingan Ketuntasan Hasil Belajar Prasiklus dan Siklus I

\begin{tabular}{cccc}
\hline No & Ketuntasan & Tuntas & Belum Tuntas \\
\hline 1 & Prasiklus & $18,75 \%$ & $81,25 \%$ \\
2 & Siklus I & $75 \%$ & $25 \%$ \\
\hline
\end{tabular}


Pada siklus I siswa sudah menunjukkan minat yang baik dalam mengikuti pembelajaran. $\mathrm{Hal}$ ini menunjukkan kenaikan yang signifikan dibandingkan dengan kondisi prasiklus walaupun masih ada siswa yang belum menunjukkan minat yang baik dalam mengikuti pembelajaran IPS.. Secara keseluruhan siklus I sudah dapat dikatakan berjalan

dengan baik, karena siswa yang menunjukkan minat baik dan mencapai ketuntasan belajar sudah mencapai $75 \%$. Dari siklus I penelitian akan dilanjutkan ke siklus II dengan perbaikan dalam beberapa hal. Hasil perbandingan ketuntasan belajar di siklus I dan siklus II adalah sebagai berikut:

Tabel 2. Persentase Perbandingan Ketuntasan Hasil Belajar Siklus I dan Siklus II

\begin{tabular}{llll}
\hline No & Ketuntasan & $\begin{array}{l}\text { Belum } \\
\text { Tuntas }\end{array}$ & Tuntas \\
\hline 1 & Siklus I & $25 \%$ & $75 \%$ \\
2 & Siklus II & $12,50 \%$ & $87,50 \%$ \\
\hline
\end{tabular}

Dari hasil penelitian yang dilakukan menunjukkan bahwa penerapan metode Inside-Outside Circle pada mata pelajaran IImu Pengetahuan Sosial kelas III di SD Negeri Wonokarto I mengalami peningkatan hasil belajar yang diperoleh dari siklus I dan siklus II. Hal ini dapat dilihat dari kondisi awal sebelum penelitian, siswa yang mendapat nilai IImu Pengetahuan Sosial mencapai KKM 70 hanya 3 $(18,75 \%)$ siswa.

Berdasarkan data hasil penelitian pada siklus I yang telah dilakukan menunjukkan peningkatan hasil belajar Matematika yang diperoleh jumlah siswa yang tuntas sebanyak 12 siswa, sehingga ada 4 siswa yang masih belum tuntas dengan nilai rata-rata kelas 80,87. Sebanyak 4 siswa yang belum tuntas tersebut dikarenakan kemampuan mereka yang kurang dan minat belajar yang masih rendah. Dari jumlah yang tuntas pada siklus I terjadi peningkatan ketuntasan sebanyak $56,25 \%$ dari sebelumnya $18,75 \%$ menjadi $75 \%$. Hal ini dapat diartikan ketuntasan secara keseluruhan belum mencapai $81,25 \%$ siswa yang tuntas belajar. Hasil penelitian ini diperkuat dengan teori bahwa metode inside ouside circle membantu siswa untuk meningkatkan pemahamannya, yang ditunjukkan dengan peningkatan hasil belajar IPS (Rahmalika, 2014:3)

Hasil pembelajaran pada siklus II diperoleh jumlah siswa yang mendapatkan nilai tuntas sebanyak 14 $(87,50 \%)$ siswa dengan nilai rata-rata kelas 84,25 . Dari jumlah siswa yang tuntas pada siklus II ini terjadi peningkatan sebanyak $12,50 \%$ dari sebelumnya $75 \%$ menjadi $87,50 \%$. Dalam hal ini, bisa diartikan bahwa ketuntasan klasikal sudah tercapai karena persentase ketuntasan belajar lebih dari $81,25 \%$ siswa yang tuntas belajar.Hasil belajar, siswa yang mencapaiKKM $\geq 70$ sudah mencapai $87,50 \%$ atau 14 siswa.

Dengan demikian, dapatdikatakan bahwa siklus II sudah memenuhi indikator kinerja yang 
ditetapkan. Jadi, berdasarkan hasil yang diperoleh di atas penggunaan metode Inside Outside Circledapat meningkatkan hasil belajar belajar
Ilmu Pengetahuan Sosial (IPS) siswa kelas III SD Negeri Wonokarto I Kecamatan Wonogiri, Wonogiri Tahun Ajaran 2015/2016.

\section{SIMPULAN}

Pembelajaran IPS dengan metode Inside-Outside Circle sangat bermanfaat bagi siswa. Sebelum dilaksanakan penelitian siswa kesulitan dengan materi yang ada dalam pembelajaran IPS dan siswa juga kurang memiliki minat yang tinggi dalammengikuti pembelajaran IPS, setelah diterapkan pembelajaran IPS menggunakan metode Inside-Outside Circlesiswa lebih memahami materi yang ada dalam pembelajaran IPS dan siswa juga lebih memiliki minat yangbaik dalam mengikuti pembelajaran. Implikasi dari penelitian ini yaitu memberi gambaran yangjelas tentang keberhasilan penerapan metode Inside-Outside Circle untuk meningkatkan hasil belajar IImu Pengetahuan Sosial pada siswa kelas III SD Negeri Wonokarto I, yang ditandai dengan meningkatnya hasil belajar siswa.

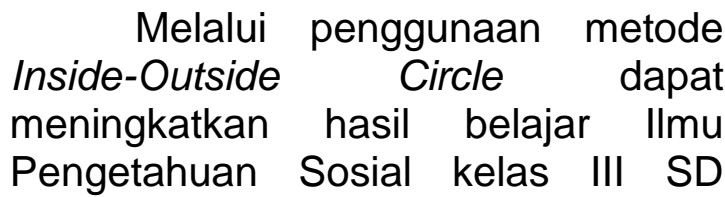
Negeri Wonokarto I dari siklus I nilai rata-rata kelas 80,87 ke siklus II nilai rata-rata kelas meningkat menjadi 84,25 . Persentase ketuntasan juga mengalami peningkatan setiap siklusnya. Persentase ketuntasan belajar siklus I mencapai $75 \%$ atau 12 siswa yang mendapat nilai tuntas dan $25 \%$ atau 4 siswa yang belum mendapat nilai tuntas. Pada siklus II persentase ketuntasan siswa meningkat hingga mencapai $87,50 \%$ atau 14 siswa yang mendapat nilai tuntas dan $12,50 \%$ atau 2 siswa yang belum mendapat nilai tuntas. Persentase ketuntasan belajar siswa telah mencapai indikator keberhasilan yaitu $(\geq 81,25 \%)$.

\section{DAFTAR PUSTAKA}

Azhary, M.A.Y.A, dkk. (2013). Penerapan Pembelajaran Kooperatif Model Inside outside Circle Untuk Meningkatkan Hasil BelajarApresiasi Dongeng Siswa Kelas Viic Mtsn Juwet Ngronggot Nganjuk. JPBSI Online, Volume 1, Nomor 1, April 2013. [diakses 0503-2016]

Helmawati. (2016). Pendidikan Keluarga. Bandung : PT Remaja Rosdakarya.
Kompri. (2016). Motivasi Pembelajaran Perspektif Guru Dan Siswa. Bandung : PTRemaja Rosdakarya.

Lie, Anita. (2014). Cooperative Learning (Mempraktikkan Cooperative Learning Di Ruangruang Kelas). Jakarta: Grasindo

Rahmalika, Pande, dkk. (2014). Pengaruh Model Pembelajaran Inside Outside Circle Dengan Time Berbantuan Multimedia Terhadap Hasil Belajar 
Ipa Kelas V Gugus 2 Denpasar Timur. e-Journal MIMBAR PGSD Universitas Pendidikan Ganesha
Jurusan PGSD (Vol. 2 No. 1 Tahun 2014). [diakses 05-032016] 